\title{
Seasonal succession in marine bacterioplankton
}

\author{
Jarone Pinhassi ${ }^{1, *}$, Åke Hagström ${ }^{2}$ \\ ${ }^{1}$ Department of Microbiology, Umeå University, 90187 Umeå, Sweden \\ ${ }^{2}$ Marine Science, Kalmar University, Box 905, 39129 Kalmar, Sweden
}

\begin{abstract}
Here we examine the seasonal distribution of marine bacterioplankton species in the northern Baltic Sea. The population density of different bacteria was determined by whole-genome DNA hybridization to community DNA. During spring, concomitant with the phytoplankton spring bloom and its decay, the bacterial community was dominated by 5 bacterial species belonging to the Flexibacter-Cytophaga-Bacteroides phylum. Together they accounted for up to $43 \%$ of the intact cells as indicated by the number of nucleoid-containing cells at this time of year $(20 \%$ of the total bacterial counts). In late June a number of new bacteria proliferated to form a summer community. The dominant bacteria during summer were largely members of the $\alpha$-Proteobacteria, with a significant contribution of Sphingomonas and Caulobacter species. The capacity of these species to cope with oligotrophic growth conditions may explain their success at this time of year, when low $\mathrm{PO}_{4}$ concentrations limit bacterial growth. The different communities were reflected in the correlation between bacterial production and temperature. During summer significantly lower levels of production at corresponding temperatures were found compared to spring and autumn. We suggest this to be a result of different physiological predisposition of the dominant bacteria during the respective seasons. A compilation of current research demonstrated the consistent finding of a low or moderate diversity in the marine environment. Thus, an understanding of how variability in physiological capacities among dominant bacterial groups results in niche differentiation is conceivable.
\end{abstract}

KEY WORDS: Aquatic bacteria - Seasonal succession - Diversity · Baltic Sea

\section{INTRODUCTION}

Bacterioplankton diversity and distribution have attracted considerable attention following the proliferation of molecular techniques, gradually revealing the identity of dominant microorganisms in aquatic environments (Rehnstam et al. 1993, Fuhrman et al. 1994, González \& Moran 1997, Pinhassi et al. 1997, Suzuki et al. 1997, Pernthaler et al. 1998). From an ecological perspective this means that the presence of bacteria can now be studied in relation to biotic and abiotic factors. Examples of this development can be seen in several recent studies. The distribution of $2 \gamma$-Proteobacteria, Comamonas acidovorans and Aeromonas hydrophila, could be explained by their different capacities to degrade organic matter, and by their ability to cope with protistan grazing (Weinbauer \& Höfle 1998).

•E-mail: jarone@micro.umu.se
Pinhassi et al. (1999) demonstrated rapid growth of specific bacteria, in response to the addition of protein to seawater, resulting in a succession of bacterial species. Murray et al. (1998) found a negative correlation between archaeal rRNA levels and chlorophyll a concentrations in Antarctic coastal waters, suggestive of competitive exclusion by Bacteria of the often 'extreme' Archaea during summer conditions (Murray et al. 1998)

In the aquatic environment the presence of bacterioplankton must be considered in both spatial and temporal dimensions. One example of varying horizontal distribution of bacteria is the bacterial species composition in Tomales Bay and San Francisco Bay. In these environments it has been suggested that differences in metabolic properties of the bacterial communities could be explained by differences in the distribution of specific bacterial populations (Hollibaugh 1994). This observation was later confirmed by comparing the banding pattern of bacterial $16 \mathrm{~S}$ rDNA fragments from 
community DNA collected in the 2 bays (Murray et al. 1996). Also, stratification of bacterial populations has been demonstrated, suggesting that microorganisms with different preferences may occupy niches determined by their vertical distribution (Giovannoni et al. 1996, Gordon \& Giovannoni 1996, Wright et al. 1997). In the central Pacific bacteria related to Chlorobium are present in high frequencies below the deep chlorophyll maximum (Gordon \& Giovannoni 1996). This is an environment with stable physical conditions, where the ubiquitous presence of these populations over time is conceivable. In temperate waters there is a strong seasonal variation in physical parameters, causing a significant seasonal succession in the phytoplankton community. This is also a likely scenario for bacteriopiankion and incieed seasonal vairation in community structure of pelagic prokaryotes has been demonstrated (Pinhassi et al. 1997, Tuomi et al. 1997, Pernthaler et al. 1998).

Despite the present rapid discovery of large numbers of marine bacterial species a low bacterial diversity has been demonstrated in marine bacterioplankton compared to soil communities. In soil, different techniques such as DNA reannealing kinetics and denaturing gradient gel electrophoresis (DGGE) profiling consistently yield much higher diversity than in aquatic samples (Ferris et al. 1996, Murray et al. 1996, Øvreås et al. 1997, 1998, Ritz et al. 1997). Since early work on natural bacterial diversity was done in soil, results showing a much less diverse community in aquatic systems have initially been surprising. However a low or moderate diversity in aquatic samples has also been suggested from theoretical considerations based on the number of bacteriophages versus bacterial numbers (Thingstad \& Lignell 1997). The implication for the marine pelagic environment is that at each site and moment in time a limited number of dominant bacterial species should be expected.

In the present study we extend an earlier analysis using whole-genome probes to determine the distribution of marine bacteria (Pinhassi et al. 1997). Here we report changes in the density of different bacterial populations in relation to changing environmental conditions. Furthermore, a presentation of their identity is given in addition to a discussion on factors structuring the bacterial community.

\section{MATERIALS AND METHODS}

Sampling. Seawater samples were collected from a depth of $4 \mathrm{~m}$ at Stn NB1, a routine sampling station in the northern Baltic Sea $\left(63^{\circ} 30^{\prime} N, 19^{\circ} 48^{\prime} \mathrm{E}\right)$, during 1995. Sampling was done every second week from April to October, and once a month during the winter season (November to March). Bacterial production and temperature measurements from 1992 to 1994 and 1996 are also included. Sampling was performed as part of the Marine Environmental Monitoring Program funded by the Swedish EPA. Primary data are stored in a database at the Umea Marine Science Center, Sweden. Temperature and salinity were measured with a Sensortec UCM 40 MK II probe. Nutrients were determined with a Technicon TRAACS 800 autoanalyser by standard methods. Methodology for primary production and chlorophyll a has been described previously (Andersson et al. 1996).

Bacterial production. Bacterial production was determined using the $\left[{ }^{3} \mathrm{H}\right]$ thymidine incorporation method (Fuhrman \& Azam 1980), as modified by Smith \& Azam (1092). Triplicate samples of $1.5 \mathrm{ml}$ were incuhated at. in situ temperatures for 1 to $2 \mathrm{~h}$ with $10 \mathrm{nM}\left[{ }^{3} \mathrm{H}\right]$ thymidine (final concentration). The standard deviation for incorporation of the radioactive label was $\leq 10 \%$ of the mean. To convert moles of incorporated thymidine to the number of cells produced a conversion factor of $1 \times 10^{18}$ cells $\mathrm{mol}^{-1}$ was applied to the samples. The conversion factor has previously been determined experimentally at Stn NB1 (Zweifel et al. 1993).

Enumeration of bacteria. Total counts of bacteria were determined by fluorescent staining. Cells preserved in $0.2 \mu \mathrm{m}$ filtered formaldehyde ( $4 \%$ final concentration) were filtered onto $0.2 \mu \mathrm{m}$ black polycarbonate filters (Micron Separations Inc.) at $100 \mathrm{~mm} \mathrm{Hg}$, and stained for $5 \mathrm{~min}$ with a $0.003 \%$ acridine orange solution (Hobbie et al. 1977). Samples were counted within $2 \mathrm{~d}$ after sampling. In the routine sampling (1992 to 1996) 4', 6-diamidino-2-phenylindole (DAPI) was used for enumeration of bacteria (Porter \& Feig 1980). Numbers of nucleoid-containing bacteria (NUCC) were quantified by staining the cells with DAPI and destaining the unspecifically bound DAPI with 2-Propanol (Zweifel \& Hagström 1995). The original protocol showed good staining due to the low salinity at the sampling site $(<6 \%)$. The number of fields (typically 20 ) were varied to maintain a standard error of the microscopic enumeration to $<5 \%$. The number of colony forming units (CFU) was determined by plating $100 \mu \mathrm{l}$ of undiluted seawater and $2 \times, 5 \times$, $10 \times$, and $20 \times$ diluted seawater samples in triplicates on Zobell agar plates (ZoBell 1946). The plates were incubated at $15^{\circ} \mathrm{C}$ in the dark. On some sampling occasions additional plates were incubated at $5^{\circ} \mathrm{C}$ and in situ temperature, for comparison, revealing no difference in final CFU.

Density of specific bacteria. The density of specific bacteria was determined by the species density protocol according to Pinhassi et al. (1997) using whole genome DNA hybridization to community DNA. For discussion on limitations of the method see Pinhassi 
et al. (1997). The procedure was as follows: during 10 sampling occasions from 6 April to 18 October 1995, approximately $20 \mathrm{l}$ of seawater was collected from $4 \mathrm{~m}$ depth at Stn NB1. The seawater was kept at in situ temperature and brought to the laboratory where samples were processed within $4 \mathrm{~h}$ after collection. Different isolates were collected from the Zobell agar plates used for the determination of CFU. The isolates were crosshybridized to weed out duplicates, and genomic DNA was prepared from each unique cell culture. Labeling of the chromosomal DNA for use as probes was performed using a Nick translation kit (Promega) and $\alpha$ - ${ }^{32} \mathrm{P}-\mathrm{dATP}$ (Ammersham), giving a specific activity of 0.1 to $1 \times 10^{8} \mathrm{cpm} \mathrm{g}^{-1}$. Probes were purified from free nucleotides using spin columns (Pharmacia).

Standard curves for each bacterial species were prepared by culturing isolates in Zobell medium (ZoBell $1946)$ at $15^{\circ} \mathrm{C}$, and harvesting the bacteria in known numbers onto hybridization membranes. Cultures were grown for 1 to $2 \mathrm{~d}$ (approx. $10^{8}$ cells $\mathrm{ml}^{-1}$ ) and thereafter 10 -fold diluted with sterile $0.2 \mu \mathrm{m}$ filtered, autoclaved seawater, from the area where the bacteria were originally isolated, and kept at $+4^{\circ} \mathrm{C}$ for $3 \mathrm{~h}$ before enumeration by direct counts and subsequent filtration. Four replicates of each standard curve with 0.5 or $1 \times 10^{5}, 3 \times 10^{5}, 6 \times 10^{5}, 1 \times 10^{6}, 2 \times 10^{6}, 5 \times$ $10^{6}$ cells in a final volume of $10 \mathrm{ml}$ were filtered onto 6 dots simultaneously. The cells were lysed on the hybridization membranes as described below for the seawater samples. The standards for each isolate were hybridized with the corresponding whole genome probe, in the same hybridization flask as the community DNA samples covering the whole sampling season.

Preparation of bacterial community DNA from the seawater samples was performed as follows. Seawater samples were prefiltered through a $2 \mu \mathrm{m}$ filter (MSI Polycarbonate). We recommend prefiltration to reduce clogging of the hybridization membranes, since $2 \mu \mathrm{m}$ filtrations do not reduce the number of bacteria. The samples were then filtered onto $0.45 \mu \mathrm{m}$ hybridization membranes (Hybond-N, Ammersham) using a blotting apparatus (GIBCO BRL with $6 \mathrm{~mm} \varnothing$ slots) with a modified lid containing twenty-four $10 \mathrm{ml}$ wells, allowing larger sampling volumes. 10 to $20 \mathrm{ml}$ of seawater was filtered at 200 to $300 \mathrm{~mm} \mathrm{Hg}$. Less than $0.1 \%$ of the bacteria were found to pass the membranes (data not shown). The samples were lysed in the dot-blot following instructions from the membrane manufacturer (Ammersham). First, the slot was covered with $100 \mu \mathrm{l}$ $0.5 \mathrm{M} \mathrm{NaOH}$ for $3 \mathrm{~min}$, the solution was filtered through, and the procedure was repeated. Second, the slot was covered with $100 \mu 1 \mathrm{M}$ Tris-HCl pH 7.4 for $5 \mathrm{~min}$, the solution was filtered through, and the proce- dure was repeated. Finally, the slot was covered with $100 \mu 1.5 \mathrm{M} \mathrm{NaCl}+0.5 \mathrm{M}$ Tris-HCl pH 7.4 for $5 \mathrm{~min}$, and the solution was filtered through. The membrane was placed on Whatman $3 \mathrm{MM}$ paper and air-dried for $15 \mathrm{~min}$. The DNA was then linked to the membrane by optimal crosslinking $\left(1200 \times 100 \mu \mathrm{J} \mathrm{cm}^{-2}, 14 \mathrm{~s}\right)$ in a XL-1000 UV crosslinker according to the manufacturer (Spectronics corporation). Alternatively, the lysis protocol according to Ammersham, of placing the membranes directly in the solutions on Saran Wrap TM, was also used. The membranes were stored at $+4^{\circ} \mathrm{C}$ until analysis.

The following hybridization conditions were used: The membranes were prehybridized in a solution consisting of $10 \times$ Denhardt (50) Denhardt: $1 \%$ Ficoll, $1 \%$ Polyvinyl pyrrolidone, $1 \% \mathrm{BSA}$ ), $4 \times$ sodium sodium citrate (SSC) $(20 \times \mathrm{SSC}: 3 \mathrm{M} \mathrm{NaCl}, 0.3 \mathrm{M} \mathrm{Na}$-citrate), $0.1 \%$ SDS, 2 mM EDTA and $100 \mu \mathrm{g} \mathrm{m}^{-1}$ Salmon Sperm DNA for at least $2 \mathrm{~h}$ at $69^{\circ} \mathrm{C}$ using a hybridization incubator (Robbins Scientific). $2 \mu \mathrm{g}$ of the probe was denatured in boiling water for $10 \mathrm{~min}$ and added to the hybridization solution. The membranes, community DNA samples and standard for each isolate were hybridized in the same hybridization flask overnight at $69^{\circ} \mathrm{C}$. The membranes were washed for $2 \times 30 \mathrm{~min}$ in $2 \times \mathrm{SSC}+0.5 \%$ SDS at the hybridization temperature and $2 \times 5 \mathrm{~min}$ in $0.1 \times \mathrm{SSC}$ at room temperature. The membranes were wrapped in saran wrap and exposed on a PhosphorImager (Molecular Dynamics) for detection of hybridization signal. The relationship between hybridization signal and number of bacteria was obtained from the slope of the standard curve for each isolate.

Cross hybridization between isolates was determined by hybridization of extracted DNA. Blotting of the DNA was carried out in accordance with the membrane manufacturer (Ammersham). The DNA extracts were diluted in $10 \times \mathrm{SSC}$ and denatured at $95^{\circ} \mathrm{C}$ for $5 \mathrm{~min}$. They were then transferred to ice and thereafter filtered onto hybridization membranes (Hybond-N, Ammersham) using a slot-blot apparatus (GIBCO BRL), after which the DNA was denatured, neutralized, and linked to the membrane as described above for sample preparation. Hybridization was performed as described above.

Continuous culture. The continuous culture experimental system consisted of 2 parallel culture vessels, each containing $1 \mathrm{l}$, that were separately fed from the medium (representing true replicates). All materials used for the preparation of the continuous cultures were soaked in $1 \mathrm{M} \mathrm{HCl}$ and then extensively rinsed with ultra pure water (Millipore Milli-Q). The flow rate was set to achieve a doubling time of $64 \mathrm{~h}$. As medium in the continuous cultures $80 \mathrm{l}$ of seawater was collected from $4 \mathrm{~m}$ depth at Stn NB1 in December 1995. The seawater was prefiltered through a $\mathrm{GF} / \mathrm{F}$ filter 
to reduce clogging and was then $0.2 \mu \mathrm{m}$ filtered at $100 \mathrm{~mm} \mathrm{Hg}$ and transferred to $20 \mathrm{l}$ polycarbonate bottles. The culture vessels were inoculated with a predator-free inoculum prepared by gravity filtration 3 times through $0.6 \mu \mathrm{m}$ polycarbonate filters (MSI). The culture was inoculated to a final abundance of $2.0 \times 10^{5}$ cells ml $^{-1}$; the bacteria were allowed to grow to the initiation of stationary phase (approximately 2.5 $\times 10^{6} \mathrm{cells} \mathrm{ml}^{-1}$ ) in the culture vessels before the flow was turned on. The continuous cultures were kept at $15^{\circ} \mathrm{C}$ in the dark, representing ambient summer temperatures at Stn NB1. The cultures were run for $3 \mathrm{mo}$ and sampling was made after $3 \mathrm{wk}$, when numbers had stabilized, and at the end of the 3 mo. Samples were collected from the outflow to avoid unintended perturbation of the culitures. On une vicdsion samples were collected directly from the vessels, yielding the same numbers.

\section{RESULTS}

The abundance of a number of numerically important bacterial species (Table 1) was monitored at a coastal marine station, from the initiation of the productive season until the onset of winter (6 April to 14 November). Tentatively, 2 bacterial communities could be assigned: a spring and a summer community were clearly separated in time, while a third group of bacteria formed a background blanket existing throughout the growth season.

Table 1. Numerically dominant bacteria in the northern Baltic Sea (Stn NB1) during 1995. 16S rRNA sequence similarity values based on nucleotide positions 130 to 500 (Escherichia coli numbering) were obtained by comparison to sequences present in GenBank using the fasta command in the GCG-package

\begin{tabular}{|c|c|c|c|}
\hline $\begin{array}{l}\text { Isolate } \\
\text { name }\end{array}$ & Access no. & Closest relative in GenBank & $\begin{array}{l}\text { milarity to closest } \\
\text { relative }(\%)\end{array}$ \\
\hline BAL3 & U63935 & Brevundimonas sp.; AJ227801 & 99.5 \\
\hline BAL8 & AF182029 & Sphingomonas sp.; Z23157 & 97.9 \\
\hline BAL11 & U63939 & Rhizomonas suberifaciens; D13737 & 97.7 \\
\hline BAL12 & & Flexibacter sp. & \\
\hline BAL17 & U63943 & Cytophaga aquatile, M58764 & 95.0 \\
\hline BAL18 & U63944 & Pseudomonas veronii; AF064460 & 99.8 \\
\hline BAL22 & U63946 & Flavobacterium aquatile; M62797 & 91.8 \\
\hline BAL23 & U63947 & Pseudomonas gessardi; AF074384 & 99.8 \\
\hline BAL29 & U63950 & Marine psychrophile; U85891 & 92.2 \\
\hline BAL31 & U63951 & Pseudomonas anguilliseptica; X99541 & 97.3 \\
\hline BAL33 & AF182030 & Sphingomonas yanoikuyae; U37524 & 98.4 \\
\hline BAL35 & AF182031 & Sphingomonas sp.; U63937 & 97.0 \\
\hline BAL37 & U63953 & Alcaligenes sp.; AJ002802 & 97.7 \\
\hline BAL4 1 & & $\gamma$-Proteobacteria & \\
\hline BAL44 & U63958 & Sphingomonas capsulata; D16147 & 93.6 \\
\hline BAL47 & U63961 & Rhodoferax fermentans; D16211 & 92.3 \\
\hline
\end{tabular}

\section{The spring community}

Beginning in April, the temperatures at Stn NB1 increased steadily from $0^{\circ} \mathrm{C}$, reaching $12^{\circ} \mathrm{C}$ in midJune. Chlorophyll $a$ and primary production values peaked in mid-April, indicating the spring phytoplankton bloom maximum which gradually declined to summer values during May (Fig. 1A). The bacterial species with the most pronounced spring occurrences were Rhizomonas suberifaciens (BAL11) and Cytophaga sp. (BAL17). R. suberifaciens displayed 1 massive peak at $1.4 \times 10^{5} \mathrm{cells} \mathrm{m}^{-1}$ on 16 May, concomitant with the phytoplankton bloom decline, while Cytophaga sp was common throughout the spring at an abundance of $8.0 \times 10^{4}$ cells ml $^{-1}$ (Fig. 2A). During the rest of the year both species remânined in the water columin in much lower although significant numbers. Somewhat similar was the dynamics of the novel $\beta$-Proteobacterium BAL47 which increased during spring, but also displayed a second peak in mid-July, accounting for $7 \%$ of the NUCC on this occasion. After the mid-summer bloom BAL47 declined again and was only found in low abundance.

\section{The summer community}

The summer of 1995 was unusually cold for the area, and the highest temperature recorded in the upper water column was $13^{\circ} \mathrm{C}$ on 6 September. Due to strong northerly winds upwelling of cold deep water occurred repeatedly (Fig. 1B). This resulted in a significant temperature decrease in the surface on $29 \mathrm{June}$ : from $12^{\circ} \mathrm{C}$ on the days before down to $5^{\circ} \mathrm{C}$. The temperature again reached $12^{\circ} \mathrm{C}$ on the next sampling occasion (13 July), and thereafter declined to a new minimum on 25 August. Finally, from the end of September temperatures slowly declined, reaching $0^{\circ} \mathrm{C}$ in December.

After the coldspell on 29 June a pronounced shift in species composition was initiated, and a number of new bacterial species started to increase in abundance. One group of species arrived at levels around $2.0 \times 10^{4}$ cells $\mathrm{ml}^{-1}$ (Fig. 2B). In this group Sphingomonas sp. (BAL35) showed a peak on 27 July with a steady decline thereafter. A few weeks later Pseudomonas anguilliseptica (BAL31) peaked at $2.5 \times$ $10^{4}$ cells $\mathrm{ml}^{-1}$ followed by Pseudomonas gessardi (BAL23) and a Flexibacter sp. (BAL12). A second group of sum- 


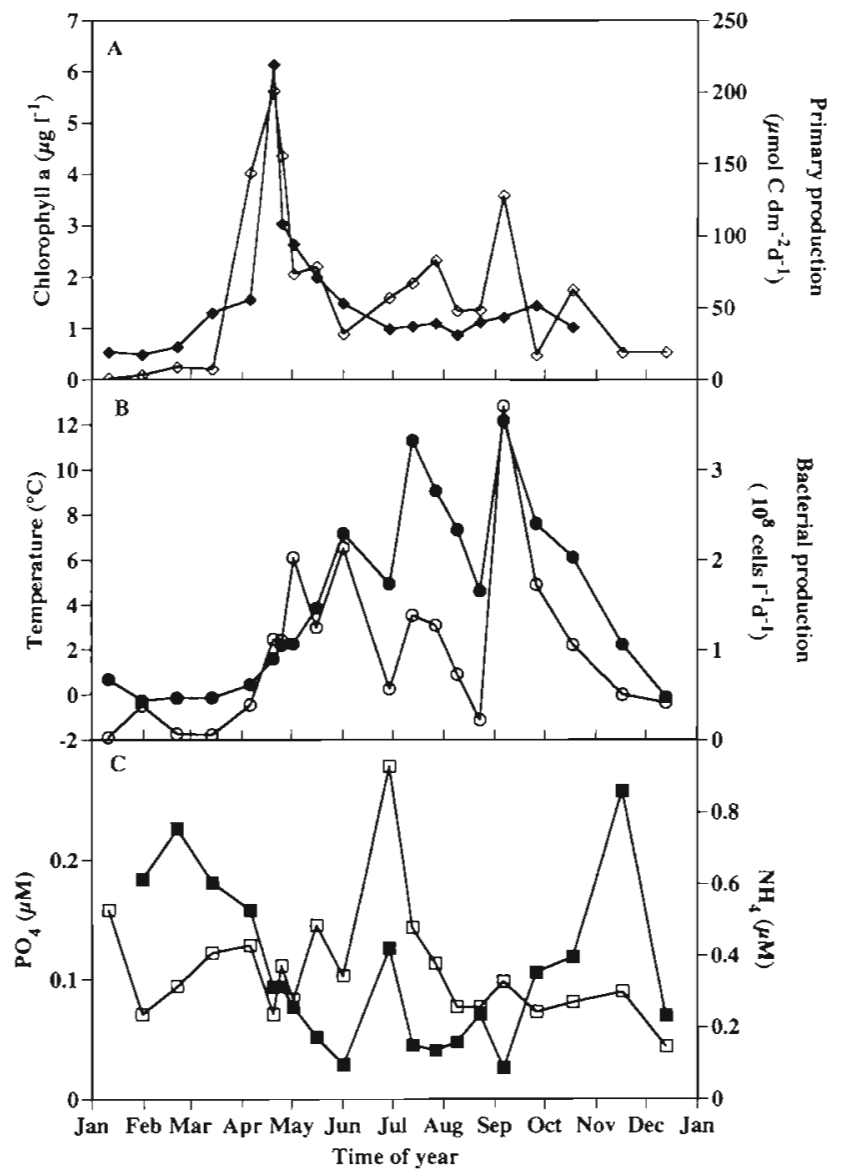

Fig. 1. Dynamics in abiotic and biotic parameters in the coastal northern Baltic Sea during 1995. (A) Change in the concentration of chlorophyll $a(\bullet)$ and primary production $(0)$. $(B)$ Dynamics in temperature $(\bullet)$ and bacterial production $(0)$. (C) Concentrations of phosphate ( $\square$ ) and ammonium (D)

mer species reached 3 times higher densities and was dominated by a species (BAL8) related to the genus Sphingomonas, reaching the highest abundance at $1.6 \times 10^{5}$ cells $\mathrm{ml}^{-1}$ (Fig. 2C). BAL8 was accompanied by Sphingomonas yanoikuyae (BAL33), a Brevundimonas species (BAL3) and the $\gamma$-Proteobacterium BAL41. These 'summer species' occurred during the period of stratification (mid-July to late August) when the $\mathrm{PO}_{4}$ concentration remained below $0.05 \mu \mathrm{M}$. No discernible annual trend was found in the $\mathrm{NH}_{4}$ concentration (Fig. 1C). The highest bacterial production and a high primary production were recorded towards the end of summer (6 September).

\section{Bacteria with a wide temporal distribution}

The $2 \gamma$-Proteobacteria Alcaligenes sp. (BAL37) and Pseudomonas veronii (BAL18), were quite abundant during the whole growth season (Fig. 2D). They thus

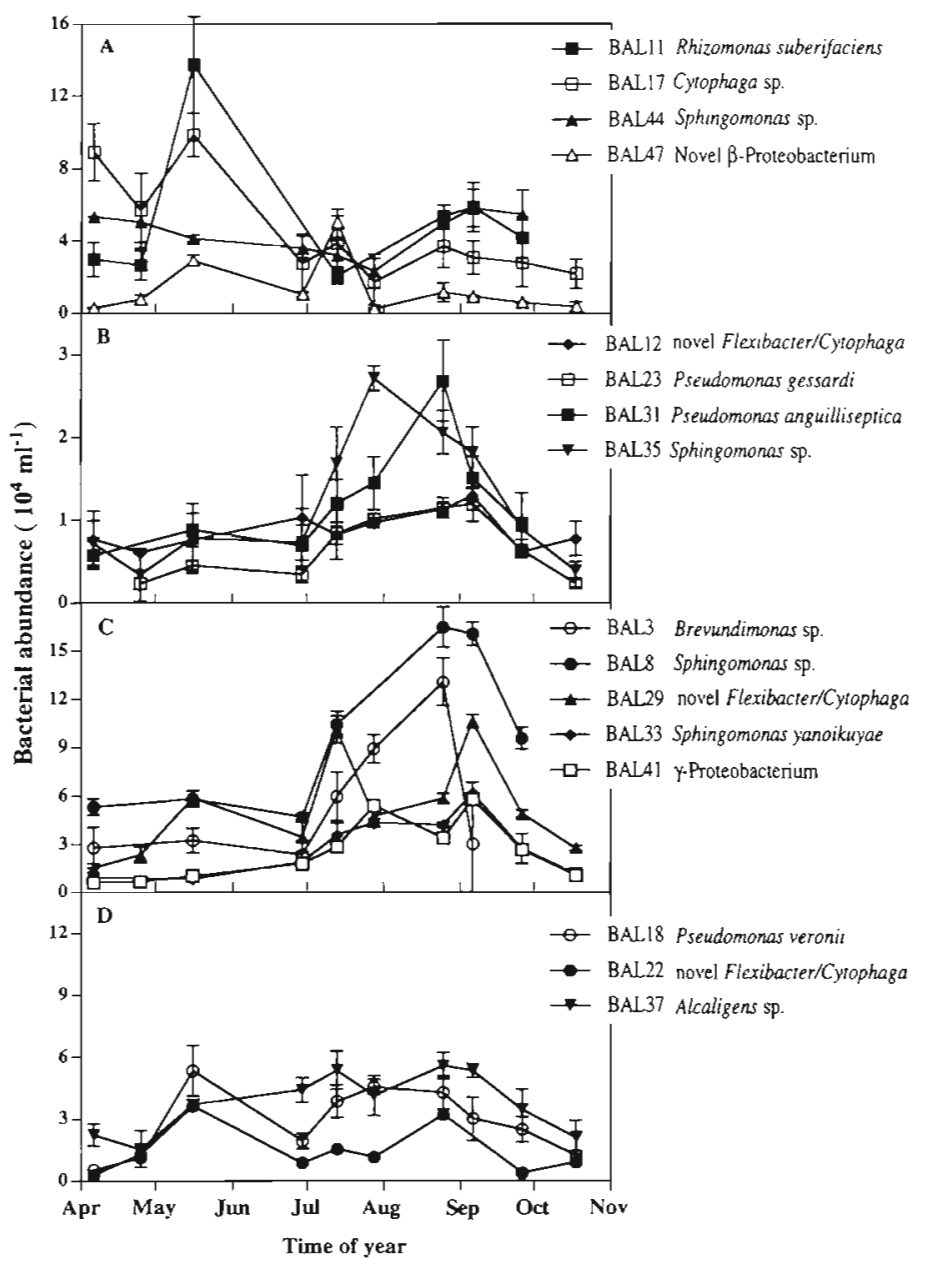

Fig. 2. Annual population dynamics of the numerically important bacterial species $\left(>2.0 \times 10^{4}\right.$ cells $\left.\mathrm{ml}^{-1}\right)$ in the northern Baltic Sea. (A) Species with pronounced peaks in spring. (B, C) Population dynamics in bacteria with peaks in abundance during summer. (D) Species with multiple peaks or maintained abundance in summer. Error bars indicate standard deviations $(\mathbf{n}=3)$

appear to represent bacteria with a generalist strategy to growth and survival. A similar pattern was seen for the novel Flexibacter-Cytophaga-Bacteroides isolate (BAL22), and Sphingomonas sp. (BAL44), which showed higher abundance in spring as well as in late summer. Another interesting distribution was shown by the novel Flexibacter-Cytophaga-Bacteroides isolate (BAL29), which showed 3 peaks during the year-each occurring when the bacterial activity was high (i.e. 16 May, 13 July, 6 September).

\section{Bacterial production and numbers}

During 1995 the bacterial total counts (TC) ranged from 1.1 to $2.2 \times 10^{6}$ cells $\mathrm{ml}^{-1}$, and NUCC ranged from 
Table 2. Measurements of bacterial total counts (TC) and the number of nucleoid-containing cells (NUCC) in the northern Baltic Sea. Also presented is the proportion of the total density of the different isolates of the total counts and number of nucleoid-containing cells during the year. Mean \pm standard deviation is given, $\mathrm{n}=15$

\begin{tabular}{|c|c|c|c|c|}
\hline \multirow{2}{*}{$\begin{array}{l}\text { Date } \\
(1995)\end{array}$} & \multicolumn{2}{|c|}{ Cell count $\left(10^{6} \mathrm{ml}^{-1}\right)$} & \multicolumn{2}{|c|}{ Species density related to } \\
\hline & Total count & NUCC (\% of TC) & $\mathrm{TC}(\%)$ & NUCC (\%) \\
\hline $6 \mathrm{Apr}$ & $1.12 \pm 0.19$ & $0.39 \pm 0.01(35)$ & 30 & 85 \\
\hline $25 \mathrm{Apr}$ & $1.27 \pm 0.27$ & $0.65 \pm 0.02(51)$ & 18 & 34 \\
\hline $16 \mathrm{May}$ & $1.69 \pm 0.32$ & $0.77 \pm 0.01(46)$ & 37 & 82 \\
\hline 29 Jun & $1.43 \pm 0.38$ & $0.88 \pm 0.01(62)$ & 22 & 36 \\
\hline $13 \mathrm{Jul}$ & $1.34 \pm 0.32$ & $1.10 \pm 0.02(79)$ & 46 & 59 \\
\hline $28 \mathrm{Jul}$ & $1.70 \pm 0.28$ & $1.00 \pm 0.02(56)$ & 26 & 46 \\
\hline $25 \mathrm{Aug}$ & $1.27 \pm 0.25$ & $0.73 \pm 0.02(57)$ & 61 & 99 \\
\hline 6 Sep & $2.16 \pm 0.40$ & $0.69 \pm 0.02(32)$ & 33 & 95 \\
\hline 26 Sep & $1.85 \pm 0.28$ & $0.51 \pm 0.01(28)$ & 23 & 82 \\
\hline $18 \mathrm{Oct}$ & $1.95 \pm 0.34$ & $0.48 \pm 0.02(25)$ & 7 & 27 \\
\hline
\end{tabular}

year. In this period bacterial production in relation to temperature was lower than during both spring and autumn (Fig. 3A). Using the specific growth rates by relating the bacterial production to total counts did not change the observed pattern. To further investigate if the relationship between bacterial production and temperature differed between summer and non-summer seasons we compiled data on these parameters from 5 consecutive years - again, a significant correlation between bacterial production and temperature during non-summer seasons was found $\left(\mathrm{p}<0.05, \mathrm{R}^{2}=0.51, \mathrm{n}=\right.$ 49; Fig. 3B). However, during summer there was no significant relationship between bacterial production and temperature.
0.4 to $1.0 \times 10^{6}$ cells $\mathrm{ml}^{-1}$. On an annual basis the proportion of NUCC accounted for 25 to $79 \%$ of the TC, with the highest proportions during summer (Table 2). The CFU were usually below $0.8 \times 10^{4} \mathrm{ml}^{-1}$, although a peak in CFU $\left(1.8 \times 10^{4} \mathrm{ml}^{-1}\right)$ occurred during the phytoplankton spring bloom decline. Minimum values in bacterial production during the growth season coincided with minimum values in temperature (Fig. 1B). The highest production value was recorded on $6 \mathrm{Sep}-$ tember, concomitant with the highest surface seawater temperature.

There was a positive correlation between water temperature and bacterial production over the year ( $\mathrm{p}<$ $0.05, R^{2}=0.73, n=19$ ). However, during the summer months the correlation differed from the rest of the

\section{Stratified conditions mimicked in continuous culture}

The summer community developed during the period of stratification when a situation approaching steady state can be anticipated. In an attempt to mimic this situation we used a continuous culture system to observe the bacterial community composition. Data from the culture are shown in Fig. $4 \mathrm{~A}, \mathrm{~B}$. In this case the TC showed good agreement with the NUCC, CFU, and the total density of the different bacteria. Since no phage particles could be detected by transmission electron microscopy for the duration of the experiment ( $3 \mathrm{mo}$ ) the culture was assumed to be free from phages, although phages were not excluded from the initial inoculum. The lack of active lytic phage infection in
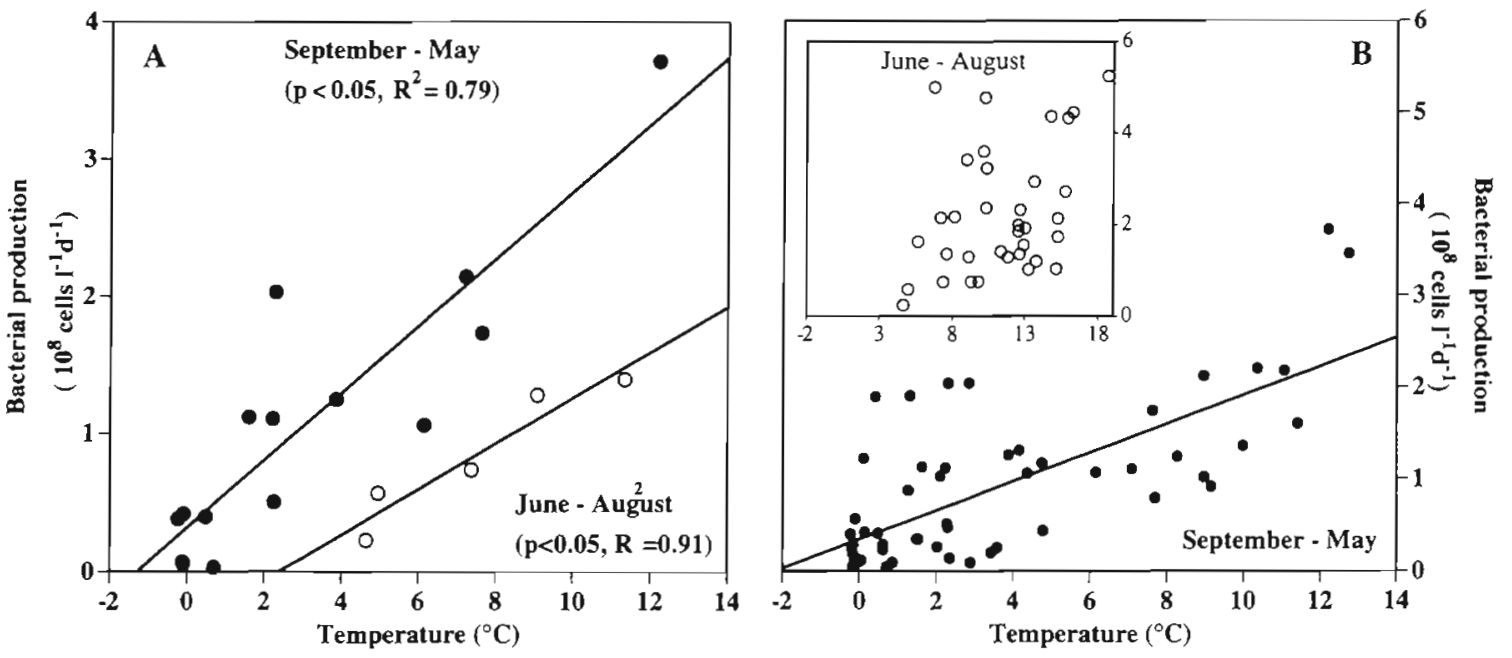

Fig. 3. Comparison of the correlation between bacterial growth and temperature in the northern Baltic Sea during summer (O) and non-summer $(\bullet$ ) seasons. (A) Bacterial production versus temperature during 1995. (B) Bacterial production versus temperature for the period 1992 to 1996; during non-summer seasons a significant correlation was found $\left(p<0.01, R^{2}=0.51\right)$, whereas the data for summer seasons were too scattered to yield any correlation 

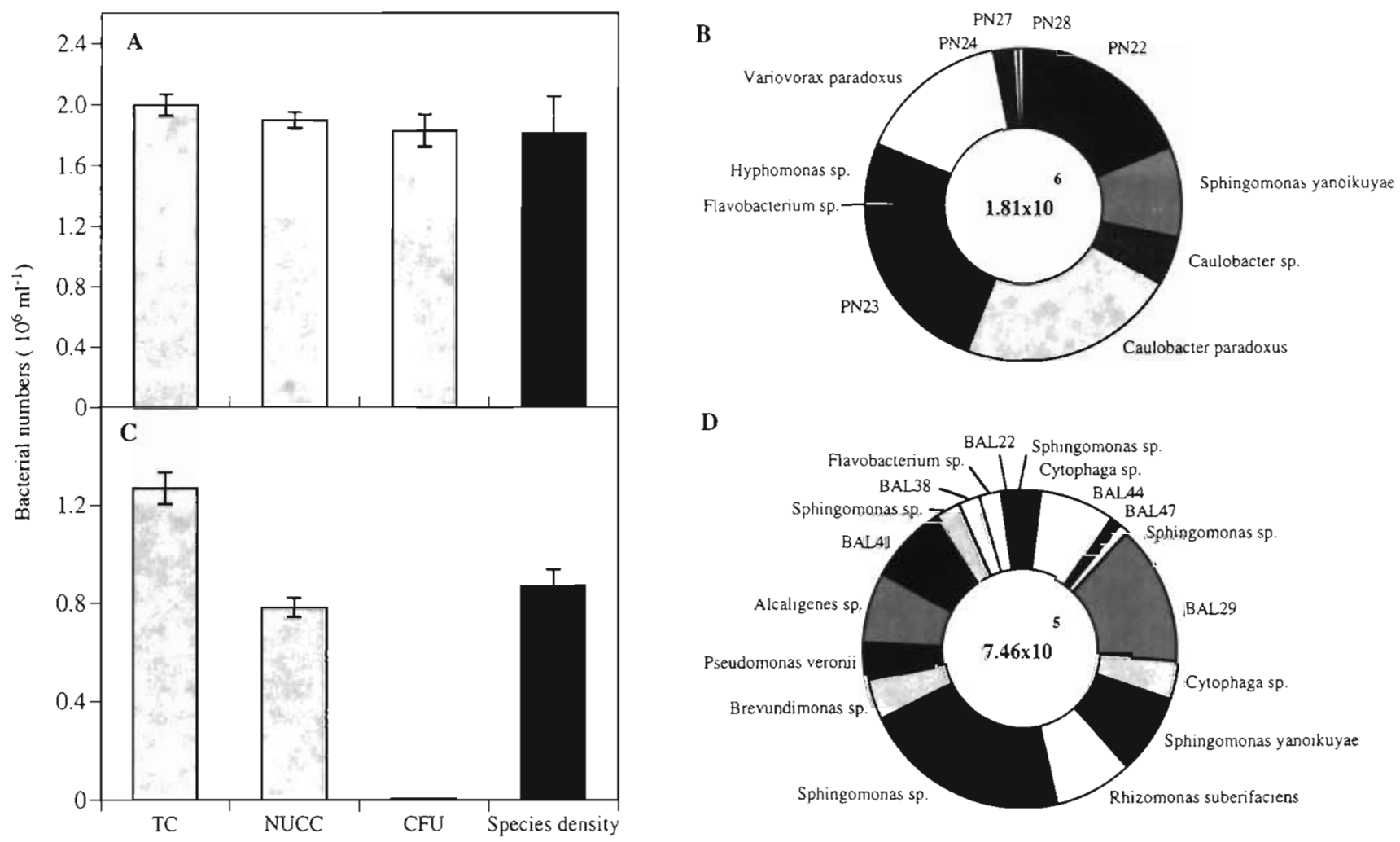

Fig. 4. Comparison of bacterial numbers estimated by different methods, and estimation of species composition in 2 aquatic systems. (A) Total abundance of 11 different bacteria in a virus-free continuous culture, compared to bacterial total counts (TC), number of nucleoid-containing cells (NUCC), and CFU. (B) Species composition in the continuous culture using seawater from NB1 as medium. (C) Total abundance of 33 different bacteria in the northern Baltic Sea (NB1) on the 6 September, compared to total counts, number of nucleoid containing cells, and CFU. (D) Species composition at NB1 on the 6 September. Error bars indicate standard deviations $(\mathrm{n}=3)$

the culture vessels possibly accounts for the agreement between TC and CFU, supporting the suggestion that phage infection can contribute to the low plating efficiency of marine bacteria (Rehnstam et al. 1993). However, analogous to the situation in situ a moderate number of dominant species was recorded by the hybridization protocol (Fig. 4B). This was in accordance with the observation that 11 species regularly occurred on the CFU plates with a $20000 \times$ dilution, indicating their abundance to be higher than $10^{4}$ cells $\mathrm{ml}^{-1}$. The hybridization protocol demonstrated that 6 of these species accounted for $87 \%$ of the bacterial numbers in the continuous culture. The dominant species were Caulobacter paradoxus, Variovorax paradoxus, Sphingomonas yanoikuyae, Hyphomonas sp. and the un. characterized isolates PN22, and PN23, with abundances ranging from 1.1 to $4.0 \times 10^{5}$ cells $\mathrm{ml}^{-1}$. During the summer situation at Stn NB1, 9 different bacteria were numerically dominant and accounted for $84 \%$ of the NUCC (Fig. 4D). On this sampling occasion there was a good agreement between the total density of the hybridized bacteria and the number of NUCC, both amounting to half of the total counts (Fig. 4C). At the same time the number of CFU remained at very low levels. The dominant bacteria were a novel Cytophaga isolate (BAL29), Cytophaga sp. (BAL17), Sphingomonas yanoikuyae (BAL33), Rhizomonas suberifaciens (BAL11), Sphingomonas sp. (BAL8), Brevundimonas sp. (BAL3), Pseudomonas veronii (BAL18), Alcaligenes sp. (BAL37), and BAL41.

\section{DISCUSSION}

\section{Succession among the bacterioplankton}

The pronounced population dynamics found in this annual study resulted in alternate bacterial communities during different seasons. The initial spring community was challenged after the upwelling in late June, when a number of new species proliferated to form a summer community (Fig. 2). In addition to the bacteria that showed pronounced changes in density we also observed a group of bacteria that formed a 
background blanket with low numbers throughout the sampling period. The question whether this reflects unfavorable growth conditions for these bacteria during the year, or if they represent species with specialized niches that only allow low densities, remains an interesting issue. Since we did not expect further development of the species composition during late autumn and winter, few samples were collected at this time. This may have been a mistake since autumn and winter peaks have been reported for Archaea and members of the genus Alcaligenes in a high mountain lake (Pernthaler et al. 1998), as well as for Bacteria and Archaea in Antarctic waters (Murray et al. 1998). The bacterial production in October and November was certainly high enough to accommodate a significant turnover of the bacterial comminity (Fig. 1D).

\section{The spring community}

During spring 5 different bacteria within the Flexibacter-Cytophaga-Bacteroides phylum together accounted for up to $43 \%$ of the NUCC (around $20 \%$ of the total counts), making them the single most important bacterial group at this time of year. The enzymatic versatility of bacteria in this phylum is well known, and has been suggested as an explanation to their importance in particle turnover (DeLong et al. 1993). In a recent mesocosm experiment, where protein was amended to simulate a phytoplankton bloom decay, increased enzymatic activities were found as Cytophaga relatives became dominant (Pinhassi et al. 1999). The bacteria affiliated with the Cytophaga species were contrasted by the presence of a few specialized species. A high density of Rhizomonas suberifacies was found during spring, although this species is characterized by its adaptation to oligotrophic growth conditions (van Bruggen et al. 1988). This bacterium is closely related to bacteria in the genus Sphingomonas based on its physiological and phylogenetic characteristics (see discussion of this genus below) (Takeuchi et al. 1994). The apparent contradiction of co-occurrence of bacteria with opposite growth strategies may be the result of mixing of the water column during spring. Weinbauer \& Höfle (1998) have demonstrated the coexistence of different bacterial species in Lake Plön. In this lake generalist bacteria were found in layers with high turnover, while more specialized species occupied parts of the more nutrient-depleted surface layer (Weinbauer \& Höfle 1998). Although only distantly related to Rhodoferax fermentans $(92.3 \%$ similarity), it is interesting to speculate on the ablities of the novel isolate BAL47 ( $\beta$-Proteobacteria), $R$. fermentans is a facultative anaerobic photoorganotroph, able to grow by either photosynthesis, aerobic respiration, or anaerobic-dark fermentation with doubling times around $3.5 \mathrm{~h}$ at 20 to $30^{\circ} \mathrm{C}$. Growth occurs in freshwater but is inhibited by more than $10 \% \mathrm{NaCl}$ (Hiraishi et al. 1991), and populations of this species have also been found to obtain a significant density in a high mountain lake (Pernthaler et al. 1998). The ability for $R$. fermentans to fix $\mathrm{N}_{2}$ has been suggested (Hiraishi et al. 1991). Another bacterium found in our study with an ability to grow under $\mathrm{N}_{2}$-fixing conditions was a member of the genus Alcaligenes (Malik \& Schlegel 1981). The capacity for nitrogen fixation of these bacteria-possibly favored by anaerobic microzones associated with abundant particles-may have important implications for our understanding of the nitrogen cycling in the Baltic.

\section{The summer community}

A conspicuous feature of the bacterial community in summer was the contribution of members of the $\alpha$-Proteobacteria. $\alpha$-Proteobacteria are important members of bacterioplankton in open oceans and coastal environments (Giovannoni et al. 1990, Fuhrman et al. 1993, Field et al. 1997, González \& Moran 1997). Notably the readily cultivable members of the $\alpha-3$ subclass of the Proteobacteria (including the Roseobacter) have a salt requirement for growth, and decline in abundance with decreasing salinity, avoiding low-saline areas (González \& Moran 1997). In the present study several Sphingomonas and a Caulobacter species were numerically dominant during summer. Interestingly, the continuous culture showed a similar dominance of these $\alpha$-Proteobacteria although, as in situ, other taxa were also present. In the culture the seawater media were supplied at a mean residence time of $64 \mathrm{~h}$. This low supply rate did create oligotrophic conditions, mimicking the stratified conditions during summer. The genus Sphingomonas was first proposed in 1990, and it was stated that bacteria in this genus are probably widely distributed in natural and artificial environments (Yabuuchi et al. 1990). Phylogenetically these bacteria have been shown to be nonphotosynthetic members of the $\alpha-4$ subclass of the Proteobacteria (Takeuchi et al. 1994). The well-characterized 'environmental' Sphingomonas sp. strain RB2256 isolated in Resurrection Bay, Alaska, harbors a high-affinity uptake system and an ability to simultaneously take up mixed substrates (Schut et al. 1993). Also, this Sphingomonas isolate shows low growth rates possibly related to a limited content of ribosomes (Fegatella et al. 1998). Adaptation to substrate and nutrientdeprived conditions also characterize Caulobacter species (Poindexter 1992). Thus, the oligotrophic characteristics of the genera Sphingomonas and Caulobacter 
are compatible with their dominance during stratified summer conditions, when nutrient concentration is low $\left(\mathrm{PO}_{4}\right.$ limits growth in the northern Baltic Sea). We thus suggest that the significance of Sphingomonas $(\alpha-4$ Proteobacteria) may be a hallmark for the bacterial summer community in the Baltic Sea as well as in other brackish water estuaries.

\section{Temperature and nutrient conditions affecting the bacterial community}

A strong positive correlation between bacterial production and temperature is regularly observed under natural conditions (Autio 1992, Shiah \& Ducklow 1994a,b, 1997, Kirchman \& Rich 1997). In the Chesapeake Bay the bacterial production was limited by temperature during non-summer seasons $\left(<20^{\circ} \mathrm{C}\right)$, while substrate supply became increasingly important during summer (Shiah \& Ducklow 1994a,b). In agreement with these authors, a significant correlation between bacterial production and temperature during nonsummer seasons was found in this study when data for 5 consecutive years were compiled (Fig. 3B). The lack of a simple relationship between temperature and bacterial production during summer (Fig. 3B) is in line with previous results showing that bacterial growth in the northern Baltic Sea is primarily $\mathrm{PO}_{4}$-limited during summer (Zweifel et al. 1995). Species succession in the bacterioplankton as a response to changing temperatures has been suggested previously (Autio 1992, Shiah \& Ducklow 1994a). Sieburth (1967) observed agreement between ambient temperatures and the temperature optima of isolated bacteria and inferred a seasonal succession of the bacteria. The same conclusion has been reached based on the optimum growth temperatures of the entire bacterioplankton community (Joint \& Pomroy 1987, Simon \& Wünsch 1998).

When the bacterial production and temperature data for 1995 were scrutinized, it appeared that the modified relationship between bacterial production and temperature during summer coincided with changes in the species composition of the bacterial community. This suggests that there were not only direct effects of temperature and nutrient concentrations on the growth of the species present, but also indirect effects through changes in the phylogenetic make up of the bacterial assemblage.

\section{Moderate diversity in marine bacterioplankton}

The term diversity of an assemblage is usually broken down into the number of species in it (species richness), and the distribution of the number of individuals amongst the species (evenness or equitability) (Walker 1989). In the present study the bacterial community on each sampling occasion was typically characterized by not more than 10 species that accounted for between 5 and $50 \%$ of the total counts, suggesting a low or moderate evenness. An obvious concern with DNADNA hybridization results is how to relate the species density to the fraction of the bacterial cells that can be assumed to contain DNA, i.e. intact cells. At present no consensus exists on how to estimate the number of active and/or intact cells in aquatic environments. Lately, Gasol et al. (1999) have demonstrated a good agreement between the number of NUCC, with bacteria showing apparent high DNA content and 'live' bacteria determined by the Live/Dead Baclight viability kit (Gasol et al. 1999). In the present study we used the NUCC as a measure of intact cells. Based on these numbers we can conclude that the dominant species accounted for between 50 and $80 \%$ of the bacterial community, which further accentuates the perception of a bacterial community with a moderate diversity. This result agrees with the fact that a low or moderate bacterial diversity appears to be a recurrent finding in the aquatic environment (Table 3). It is also worth noting that a significant proportion of $16 \mathrm{~S}$ rDNA sequences recovered by direct cloning from marine pelagic community DNA belong to a limited number of clusters (e.g. SAR11 and SAR86), which further corroborates our results (see Giovannoni et al. 1996). Having said this, we realize that the final word on the number of species found in these clusters has not been printed yet. However, it makes a great difference if we deal with a community dominated by few species, or a highly diverse community with hundreds of equally abundant bacteria. Only in a situation with a low number of dominant species is it feasible to resolve the growth pattern of different bacterial populations in relation to regulating factors.

The isolated bacteria showed a large phylogenetic diversity with members from the $\alpha$-, $\beta$-, an $\gamma$-subclasses of the Proteobacteria as well as members of the Flexibacter-Cytophaga-Bacterioides phylum. A majority of these bacteria showed low 16S rRNA gene sequence homology (0.84 to 0.95) to previously identified bacteria (Pinhassi et al. 1997). In the Baltic Sea several species of the genera Pseudomonas, Cytophaga, Caulobacter, and Alcaligenes are regularly isolated - all of which tend to form conspicuous colonies on agar plates. Genera lacking in our collection of isolates from the northern Baltic Sea are Vibrio, Alteromonas and Pseudoalteromonas, presumably due to their salt requirement for growth (Hagström et al. 2000, in this issue). Höfle \& Brettar (1996) have examined the taxonomic diversity among bacteria able to form colonies on solid media in the central Baltic Sea. A majority of the isolates (72\%) could be 
Table 3. Number of numerically dominant bacteria in different aquatic environments and soil, determined by different techniques. Levels of diversity obtained by similar methods in soil are shown for comparison. DGGE: Denaturing gradient gel electrophoresis, LMW RNA; low molecular weight RNA (5S IRNA and tRNA)

\begin{tabular}{|c|c|c|c|c|}
\hline Study area & Water volume & No. of dominant species & Approach & Source \\
\hline Scripps Pier & Coastal, surface & $2-5$ & Oligonucleotide hybridization & Rehnstam et al. (1993) \\
\hline Antarctic & Coastal, offshore & 5 (out of total 31 ) & DGGE & Murray et al. (1998) \\
\hline Baltic Sea & Offshore, all depths & $3-7$ & LMW RNA electrophoresis & Höfle \& Brettar (1995) \\
\hline Scripps Pier & Coastal & $7-10$ & Whole-genome DNA hybridization & Pinhassi et al. (1999) \\
\hline Baltic Sea & Coastal & $8-14$ & Whole-genome DNA hybridization & Present study \\
\hline Arabian Sea & Coastal, offshore & 15 amplicons & DGGE & Riemann et al. (1999) \\
\hline Norway & Meromictic lake & $10-20$ & DGGE & Øvreås et al. (1997) \\
\hline $\begin{array}{l}\text { Theoretical } \\
\text { prediction }\end{array}$ & $\begin{array}{l}\text { Aquatic } \\
\text { environments }\end{array}$ & $\leq 50$ species & $\begin{array}{l}\text { Prediction based on } \\
\text { virus infection }\end{array}$ & Thingstad \& Lignell (1997) \\
\hline Denmark & Lake water & 165 different genomes & DNA reannealing & Ritz et al. (1997) \\
\hline Norway & Pasture soil & $\begin{array}{l}>100 \text { (bands covering } \\
\text { the whole gradient) }\end{array}$ & DGGE & Øvreås et al. (1998) \\
\hline UK & Pasture soil & 1000 different genomes & DNA reannealing & Ritz et ai. $(i 99 \overline{7})$ \\
\hline Norway & Forest soil & 4000 different genomes & DNA reannealing & Torsvik et al.(1990) \\
\hline
\end{tabular}

assigned to Shewanella putrefaciens and a $p_{\text {seudomonas species, while the remaining fraction was }}$ represented by a number of different taxa. In addition to the genera mentioned above we found a notably large number of $\alpha$-Proteobacteria. We have found no previous reports on Sphingomonas, Rhodobacter, and Rhizomonas species in the Baltic Sea. This is likely due to their very inconspicuous colony morphology on agar plates, which can easily be over-looked or over-grown. It is important to stress that a moderate diversity in the acting bacterioplankton community does not make it unlikely to find a vast number of different bacterial species (i.e. high species richness) when sample size, sampling location and time is varied.

\section{Viral infection and species diversity}

In this study it was evident that single bacterial species persisted at high abundance for long periods - up to several weeks. Such temporal persistence has also been reported elsewhere (Rehnstam et al. 1993, Vergin \& Giovannoni 1998). However, in view of the high number of phages in seawater the maintenance of a high abundance of potential hosts is surprising. Phage infection is dependent on the frequency of collision between phages and hosts, and threshold for host abundances of between $10^{2}$ and $10^{4} \mathrm{ml}^{-1}$ for successful phage replication to take place has been demonstrated in pure cultures (Wiggins \& Alexander 1985, Kokjohn et al. 1991). Wilcox \& Fuhrman (1994) extrapolated from seawater cultures, that a total number of bacterial cells above $3 \times 10^{5} \mathrm{ml}^{-1}$ would be required for successful lytic infection. They also highlighted that the higher the bacterial diversity in the sample, the lower the abundance of each potential host would be, ultimately hindering phage propagation (Wilcox \& Fuhrman 1994). In our study, as in other studies of bacterial distribution, a low number of species frequently made up a majority of the bacterial numbers (Table 3). Based on this information the existence of propagating phages is likely and would indicate a continuous onslaught on bacterial cells. The long periods of dominance of single bacterial species would thus require either that there is a constant evolution of resistance among the hosts, and/or that the phages have a low infection rate. Thingstad \& Lignell (1997) argued that based on a 'killing the winner' concept much of the control of bacterial diversity should be dependent on phage infection. This may however be too simple an explanation since in our continuous culture experiment several bacterial species were maintained in the culture vessels, in spite of a lack of phages as indicated by electron microscopy. A lack of phage replication in seawater cultures was described by Wilcox \& Fuhrman (1994), when small inocula were used. In these cultures small initial numbers of bacteria caused an inactivation of the phages before any bacteria reached an abundance high enough for successful phage propagation to be initiated (Wilcox \& Fuhrman 1994). Control of bacterioplankton diversity could also be assumed based on a recent model on competitive exclusion (Siegel 1998). This work mainly addressed the issue of how phytoplankton diversity can be maintained in a seemingly homogeneous environment, but also included data valid for bacteria. It was demonstrated that the rates of direct competition decrease with decreasing cellular abundance and size. For cells in the bacterial range of abundance $<10^{7} \mathrm{ml}^{-1}$ and size $<2 \mu \mathrm{m}$ the rate of competitive displacement should be low, allowing coexistence of multiple bacterial species on a single limiting nutrient (Siegel 1998). 
In this paper we have demonstrated a pronounced seasonal succession in marine bacterioplankton. Most likely changes in, e.g., temperature, $\mathrm{PO}_{4}$ concentration and chlorophyll a favored the growth of phylogenetically different bacteria at different times of the year. This suggests the possibility to determine how variability in physiological capacities results in niche differentiation, ultimately leading to a further understanding of forces structuring bacterial diversity in marine bacterioplankton.

Acknowledgements. We thank Johanna Hemphälä and Asa Rudehäll for excellent technical assistance, and the staff at Umea Marine Science Center for great assistance with sampling. The valuable contributions by 2 anonymous reviewers are gratefully acknowledged. This work was supported by the Swedish Natural Science Council (NFR), grant BU 04452-321 to $\AA . H$.

\section{LITERATURE CITED}

Andersson A, Hajdu S, Haecky P, Wikner J, Kuparinen J (1996) Succession and growth limitation of phytoplankton in the Gulf of Bothnia (Baltic Sea). Mar Biol 126:791-801

Autio RM (1992) Temperature regulation of brackish water bacterioplankton. Arch Hydrobiol Beih Ergeb Limnol 37:253-263

DeLong EF, Franks DG, Alldredge AL (1993) Phylogenetic diversity of aggregate-attached vs. free-living marine bacterial assemblages. Limnol Oceanogr 38:924-934

Fegatella F, Lim J, Kjelleberg S, Cavicchioli R (1998) Implications of rRNA operon copy number and ribosome content in the marine oligotrophic ultramicrobacterium Sphingomonas sp. RB2256. Appl Environ Microbiol 64:4433-4438

Ferris MJ, Muyzer G, Ward DM (1996) Denaturing gradient gel electrophoresis profiles of $16 \mathrm{~S}$ rRNA-defined populations inhabiting a hot spring microbial mat community. Appl Environ Microbiol 62:340-346

Field KG, Gordon D, Wright T, Rappé M, Urbach E, Vergin K, Giovannoni SJ (1997) Diversity and depth-specific distribution of SAR11 cluster rRNA genes from marine planktonic bacteria. Appl Environ Microbiol 63:63-70

Fuhrman JA, Azam F (1980) Bacterioplankton secondary production estimates for coastal waters of British Columbia Antarctica, and California. Appl Environ Microbiol 39: $1085-1095$

Fuhrman JA, McCallum K, Davis AA (1993) Phylogenetic diversity of subsurface marine microbial communities from the Atlantic and Pacific oceans. Appl Environ Microbiol 59:1294-1302

Fuhrman JA, Lee SH, Masuchi Y, Davis AA, Wilcox RM (1994) Characterization of marine procaryotic communities via DNA and RNA. Microb Ecol 28:133-145

Gasol JM, Zweifel UL, Peters F, Fuhrman JA, Hagström $\AA$ (1999) Significance of size and nucleic acid content heterogeneity as measured by flow cytometry in natural planktonic bacteria. Appl Environ Microbiol 65:4475-4483

Giovannoni SJ, Britschgi TB, Moyer CL, Field KJ (1990) Genetic diversity in Sargasso Sea bacterioplankton. Nature 345:60-63

Giovannoni SJ, Rappé MS, Vergin KL, Adair NL (1996) $16 \mathrm{~S}$ rRNA genes reveal stratified open ocean bacterioplankton populations related to the green non-sulfur bacteria. Proc Natl Acad Sci USA 93:7979-7984
González JM, Moran MA (1997) Numerical dominance of a group of marine bacteria in the alpha-subclass of the class Proteobacteria in coastal seawater. Appl Environ Microbiol 63:4237-4242

Gordon DA, Giovannoni SJ (1996) Detection of stratified microbial populations related to Chlorobium and Fibrobacter species in the Atlantic and Pacific oceans. Appl Environ Microbiol 62:1171-1177

Hagström \&, Pinhassi J, Zweifel UL (2000) Biogeographical diversity among marine bacterioplankton. Aquat Microb Ecol 21:231-244

Hiraishi A, Hoshino Y, Satoh T (1991) Rhodoferax fermentans gen. nov., sp. nov., a phototrophic purple nonsulfur bacterium previously referred to as the 'Rhodocyclus gelatinosus-like' group. Arch Microbiol 155:330-336

Hobbie JE, Daley RJ, Jasper S (1977) Use of nucleopore filters for counting bacteria by fluorescence microscopy. Appl Environ Microbiol 33:1225-1228

Hofle M, Brettar I (1995) Taxonomic diversity and metabolic activity of microbial communities in the water column of the central Baltic Sea. Limnol Oceanogr 40:868-874

Höfle MG, Brettar I (1996) Genotyping of heterotrophic bacteria from the central Baltic Sea by use of low-molecularweight RNA profiles. Appl Environ Microbiol 62:1383-1390

Hollibaugh JT (1994) Relationship between thymidine metabolism, bacterioplankton community metabolic capabilities and sources of organic matter used for growth. Microb Ecol 28:117-131

Joint IR, Pomroy AJ (1987) Activity of heterotrophic bacteria in the euphotic zone of the Celtic Sea. Mar Ecol Prog Ser 41:155-165

Kirchman DL, Rich JH (1997) Regulation of bacterial growth rates by dissolved organic carbon and temperature in the equatorial Pacific Ocean. Microb Ecol 33:11-20

Kokjohn TA, Sayler GS, Miller RV (1991) Attachment and replication of Pseudomonas aeroginosa bacteriophages under conditions simulating aquatic environments. J Gen Microbiol 137:661-666

Malik KA, Schlegel HG (1981) Chemolithoautotrophic growth of bacteria able to grow under $\mathrm{N}_{2}$-fixing conditions. FEMS Microbiol Lett 11:63-67

Murray AE, Hollibaugh JT, Orrego C (1996) Phylogenetic composition of bacterioplankton from two California estuaries compared by denaturing gradient gel electrophoresis of $16 \mathrm{~S}$ rDNA fragments. Appl Environ Microbiol 62: $2676-2680$

Murray AE, Preston CM, Massana R, Taylor LT, Blakis A, Wu K, DeLong EF (1998) Seasonal and spatial variability of bacterial and archaeal assemblages in the coastal waters near Anvers Island, Antarctica. Appl Environ Microbiol $64: 2585-2595$

Øvreås L, Forney L, Daae FL, Torsvik V (1997) Distribution of bacterioplankton in meromictic lake Sælenvannet, as determined by denaturing gradient gel electrophoresis of PCR-amplified gene fragments coding for 16S rRNA. Appl Environ Microbiol 63:3367-3373

Øvreås L, Jensen S, Daae FL, Torsvik V (1998) Microbial community changes in a perturbed agricultural soil investigated by molecular and physiological approaches. Appl Environ Microbiol 64:2739-2742

Pernthaler J, Glöckner FO, Unterholzner S, Alfreider A, Psenner R, Amann R (1998) Seasonal community and population dynamics of pelagic Bacteria and Archaea in a high mountain lake. Appl Environ Microbiol 64:4299-4306

Pinhassi J, Zweifel UL, Hagström § (1997) Dominant marine bacterioplankton species found among colony-forming bacteria. Appl Environ Microbiol 63:3359-3366 
Pinhassi J, Azam F, Hemphälä J, Long RA, Martinez J, Zweifel UL, Hagström $\AA$ (1999) Coupling between bacterioplankton species composition, population dynamics, and organic matter degradation. Aquat Microb Ecol 17: $13-26$

Poindexter JS (1992) Dimorphic prosthecate bacteria: the genera Caulobacter, Asticcaulis, Pedomicrobium, Hyphomonas, and Thiodendron. In: Balows A, Trüper HG, Dworkin M, Harder W, Schleifer KH (eds) The prokaryotes. Springer-Verlag, New York, p 2176-2196

Porter KG, Feig YS (1980) The use of DAPI for identifying and counting aquatic microflora. Limnol Oceanogr 25:943-948

Rehnstam AS, Bäckman S, Smith DC, Azam F, Hagström $\AA$ (1993) Blooms of sequence-specific culturable bacteria in the sea. FEMS Microbiol Ecol 102:161-166

Riemann L, Steward GF, Fandino LB, Campbell L, Landry MR, Azam F (1999) Bacterial community composition during two consecutive NE monsoon periods in the Arabian Sea studied by denaturing gradient gel electrophoresis (DGGE). Deep-Sea Res II 46:1791-1811

Ritz K, Griffiths BS, Torsvik VL, Hendriksen NB (1997) Analysis of soil and bacterioplankton community DNA by melting profiles and reassociation kinetics. FEMS Microbiol Lett 149:151-156

Schut F, DeVries EJ, Gottschal JC, Robertson BR, Harder W, Prins RA, Button DK (1993) Isolation of typical marine bacteria by dilution culture: growth, maintenance and characteristics of isolates under laboratory conditions. Appl Environ Microbiol 59:2150-2160

Shiah FK, Ducklow HW (1994a) Temperature and substrate regulation of bacterial abundance, production and specific growth reate in Chesapeake Bay, USA. Mar Ecol Prog Ser 103:297-308

Shiah FK, Ducklow HW (1994b) Temperature regulation of bacterioplankton abundance, production, and specific growth rate in Chesapeake Bay. Limnol Oceanogr 39: 1243-1258

Shiah FK, Ducklow HW (1997) Bacterioplankton growth responses to temperature and chlorophyl variations in estuaries measured by thymidine:leucine incorporation ratio. Aquat Microb Ecol 13:151-159

Sieburth JM (1967) Seasonal selection of estuarine bacteria by water temperature. J Exp Mar Biol Ecol 1:98-121

Siegel DA (1998) Resource competition in a discrete environment: why are plankton distributions paradoxical? Limnol Oceanogr 43:1133-1146

Simon M, Wünsch C (1998) Temperature control of bacterioplankton growth in a temperate large lake. Aquat Microb Ecol 16:119-130

Smith DC, Azam F (1992) A simple, economical method for measuring bacterial protein synthesis rates in seawater using ${ }^{3} \mathrm{H}$-leucine. Mar Microb Food Webs 6:107-114

Suzuki MT, Rappé MS, Haimberger ZW. Winfield $H$, Adair N, Ströbel J, Giovannoni SJ (1997) Bacterial diversity among small-subunit rRNA gene clones and cellular isolates from

Editorial responsibility: Tom Fenchel,

Helsingør, Denmark the same seawater sample. Appl Environ Microbiol 63 : 983-989

Takeuchi M, Sawada $\mathrm{H}$, Oyaizu $\mathrm{H}$, Yokota A (1994) Phylogenetic evidence for Sphingomonas and Rhizomonas as nonphotosynthetic members of the alpha- 4 subclass of the Proteobacteria. Int J Syst Bacteriol 44:308-314

Thingstad TF, Lignell R (1997) Theoretical models for the control of bacterial growth rate, abundance, diversity and carbon demand. Aquat Microb Ecol 13:19-27

Torsvik V, Goksoyr J, Daae FL (1990) High diversity in DNA of soil bacteria. Appl Environ Microbiol 56:782-787

Tuomi P, Torsvik T, Heldal M, Bratbak G (1997) Bacterial population dynamics in a meromictic lake. Appl Environ Microbiol 63:2181-2188

van Bruggen AHC, Grogan RG, Bogdanoff CP, Waters CM (1988) Corky root of lettuce in California caused by a Gram-negative bacterium. Phytopathology 78:1139-1145

Vergin KL, Giovannoni SJ (1998) Seasonal and vertical patterns in bacterinnlankton rommunities at BATS. 1998 Ocean Sciences Meeting, OS26, Supplement to EOS, Transactions, American Geophysical Union, Vol 79

Walker D (1989) Diversity and stability. In: Cherrett JM (ed) Ecological concepts. Blackwell Scientific Publications, Oxford, p 115-145

Weinbauer MG, Höfle MG (1998) Distribution and life strategies of two bacterial populations in a eutrophic lake. Appl Environ Microbiol 64:3776-3783

Wiggins BA, Alexander M (1985) Minimum bacterial density for bacteriophage replication: implications for significance of bacteriophages in natural ecosystems. Appl Environ Microbiol 49:19-23

Wilcox RM, Fuhrman JA (1994) Bacterial viruses in coastal sea water: lytic rather than lysogenic production. Mar Ecol Prog Ser 114:35-45

Wright TD, Vergin KL, Boyd PW, Giovannoni SJ (1997) A novel $\partial$-subdivision proteobacterial lineage from the lower ocean surface layer. Appl Environ Microbiol 63:1441-1448

Yabuuchi E, Yano I, Oyaizu H, Hashimoto Y, Ezaki T, Yamamoto H (1990) Proposals of Sphingomonas paucimobilis gen. nov. and comb. nov., Sphingomonas parapaucimobilis sp. nov., Sphingomonas yanoikuyae sp. nov., Sphingomonas adhesiva sp. nov., Sphingomonas capsulata sp. nov, and two genospecies of the genus Sphingomonas Microbiol Immunol 34:99-119

ZoBell CE (1946) Marine microbiology: a monograph on hydrobacteriology. Cronica Botanica Co, Waltham, MA

Zweifel UL, Hagstrom $\AA$ (1995) Total counts of marine bacteria include a large fraction of non-nucleoid-containing 'ghosts' Appl Environ Microbiol 61:2180-2185

Zweifel UL, Norrman B, Hagström $\AA$ (1993) Consumption of dissolved organic carbon by marine bacteria and demand for inorganic nutrients. Mar Ecol Prog Ser 101:23-32

Zweifel UL, Wikner J, Hagström $\AA$, Lundberg E, Norrman B (1995) Dynamics of dissolved organic carbon in a coastal ecosystem. Limnol Oceanogr 40:299-305

Submitted: September 7, 1999; Accepted: February 29, 2000

Proofs received from author(s): April 11, 2000 